\title{
THE EFFECTIVITY TEST OF ALOE VERA LEAF EXTRACT TO LARVAE AEDES SP
}

\author{
ROMASEPFANI LUBIS ${ }^{1}$, SYAFRUDDIN ILYAS ${ }^{1,2 *}$, MERINA PANGGABEAN ${ }^{1}$
}

${ }^{1}$ Department of Tropical Medicine, Faculty of Medicine, Universitas Sumatera Utara, Medan, Indonesia. ${ }^{2}$ Departement of Biology, Faculty of Mathematics and Natural Sciences, Universitas Sumatera Utara, Medan, Indonesia. Email: syafruddin6@usu.ac.id

Received: 02 February 2018, Revised and Accepted: 10 April 2018

ABSTRACT

Objective: Virus control was pressed to terminate transmission chain by reducing mosquito populations. One effective alternative was biological control vector using plant extracts. The purpose of this study was to assess the lethal concentration median $\left(\mathrm{LC}_{50}\right)$ and effective time to kill the larvae.

Methods: Aloe vera leaf washed with water, then envy transverse with a thickness and dried in a drying cupboard. Further, the prepare to percolation $A$. vera leaf extract was characterized liquid extract the next in the freeze dryer. Enter 25 larvae into each glass of research that has been mixed $A$. vera leaf extract with various concentrations: 20 ppm; 40 ppm; 60 ppm; 80 ppm; and 100 ppm, negative control (water) and abate $(1$ ppm) as a positive control. Further, to observe the number of dead larvae in the studied glass at 180, 360, 1440, and $2880 \mathrm{~min}$.

Results: A probit analysis was used to determine concentrations in killing larvae. A. vera leaf extract concentration was effective to kill $50 \%$ of test larvae with $\mathrm{LC}_{50}$ at $80.5 \mathrm{ppm}$ with $1440 \mathrm{~min}$ observation time.

Conclusion: A. vera extract can be larvicidal because it has the secondary metabolite compounds which toxic substances to mosquito larvae with the $\mathrm{LC}_{50}$ value of $80.5 \mathrm{ppm}$ at $1440 \mathrm{~min}$.

Keywords: Aedes sp, Aloe vera, Larvicide

(C) 2018 The Authors. Published by Innovare Academic Sciences Pvt Ltd. This is an open access article under the CC BY license (http://creativecommons. org/licenses/by/4. 0/) DOI: http://dx.doi.org/10.22159/ajpcr.2018.v11i7.24463

\section{INTRODUCTION}

Diseases transmitted by mosquitoes and other insect vectors continue to place a critical burden on the world's poor, particularly in tropical and subtropical areas [32]. The most common diseases caused by mosquitoes were dengue fever, chikungunya, malaria, filariasis, and dengue hemorrhagic fever (DHF) [15].

DHF was an infectious disease and spread by Aedes sp mosquitoes containing dengue virus. Aedes species vectors in the world were Aedes aegypti, Aedes albopictus, Aedes scutellaris, Aedes mediovittatus, and Aedes polynesiensis [3]. Female A. aegepty and A. albopictus were very potential in causing dengue disease[12]. A. aegypti larvae prefer to live in the clear water such as flower pots and bathtubs. While A. albopictus mosquitoes more activities outside the home, in the garden, and in the yard [26]. Thus, the mosquito will suck the human outdoors, perched on leaves and tree trunks, vases, water storage, drums, scrap tires, and sewers [7]. Similarly, A. albopictus larvae were also commonly found outside the home, for example, at the base of leaves, tin cans, scrap tires, bamboo pieces, tree stumps, and bottles, sometimes larvae still found in the clear water/no little food [5]. Aedes sp female mosquitoes can produce up to 100 eggs when it has sucked human blood. Eggs found the dry place (without water) can last up to 6 months. These eggs will then hatch into larvae after about 1-2 days if it submerged in water [13].

According to the Department of Health 2014, Asia ranks first in the number of DHF patients each year from worlds. In 2013, it cases died as 871 people from 112,511 residents $(0.7 \%)$. It cases increased in 2014 where 641 people died from 71,668 (0.89\%). Several provinces go through into increase cases, including North Sumatra, Riau, Riau Islands, DKI Jakarta, West Kalimantan, North Sulawesi, Bali, and North Kalimantan. The North Sumatra Summit identifies three districts/ cities with KLB (extraordinary) at 2014 as Labuhan Batu, Labuhan Batu Utara, and Binjai City. Of the three districts/cities were reported as seven peoples with DHF died. Dengue cases more increasing along with a shift of the area from the rural areas made urban due to the development and environmental changes so that it can affect to host and trigger the occurrence of disease or epidemic, it was an effort to overcome the Aedes sp as a DBD vector [4].

Virus control was pressed to terminate transmission chain by reducing mosquito populations and preventing mosquito contact with humans. The control of mosquito larvae populations generally by applying insecticides to breeding grounds, but the use of excessive synthetic insecticides has created new problems of resistance and side effects. Continuous use of synthetic insecticides can result in non-targeted animal deaths, loss or death of natural enemies, environmental degradation of ecosystem proportion, and cause resistance mosquitoes [19]. One effective alternative was biological control vector using plant extracts [25]. Higher plants as sources of bioactive compounds continue to play a dominant role in the maintenance of human health. Reports available on green plants represent a reservoir of effective chemotherapeutants, these are non-phytotoxic, more systemic, and easily biodegradable [24].

Plants are a rich source of alternative agents for control of mosquitoes because they possess bioactive chemicals, which act against the limited number of species including specific target-insects and are eco-friendly. Conventionally plant-based products have been used in human communities for many centuries for managing insects. Several secondary metabolites present in plants serve as a defense mechanism against insect attacks. This bioactive chemicals may act as insecticides, antifeedants, molting hormones, oviposition deterrents, repellents, juvenile hormone mimics, growth inhibitors, anti-molting hormones, and attractants. Plant-based pesticides are less toxic, delay the development of resistance because of its new structure and easily biodegradable [23].

The use of natural larvacides has several advantages, such as rapid degradation or decomposition by sunlight, air, moisture, and 
other natural components. It is reducing the risk of soil and water contamination. Furthermore, most natural larvacides have low toxicity in mammals because it was natural larvacides to allow it to be applied to human life [11]. Many studies use plants as larvicides by observing lethal concentration (LC) and lethal time (LT). LC was measure toxicity of a pesticide type. LT was a time it takes for a substance to cause death. On effectiveness test showed LC where percent concentration which can cause $50 \%$ mortality of animal experiment and $\mathrm{LT}_{50}$ showed how much concentration of a substance to kill $50 \%$ of experimental animals. One of the potential larvicidal was Aloe vera plants [2]. A. vera leaves were a family of Liliaceae [1] and belong to the genus Aloe which contains water, vitamins, minerals, enzymes, polysaccharides, and glycoproteins. A. vera leaves also contain secondary metabolites such as saponins, tannins, flavonoids, and alkaloids. It is an agent of larvicidal [24].

Aloe sp extract has larvacide activity against $A$. aegypti [7]. A. vera leaves have a larvicidal effect on $A$. aegypti larvae Instar I, II, III, and IV with each value of LC median $\left(\mathrm{LC}_{50}\right.$ ) 162,74; 201,43; 253,30; and 300,05 ppm [24]. Efficacy of $A$. vera carbon tetrachloride extract had a larvicidal effect on Culex quinquefasciatus with $\mathrm{LC}_{50}$ of $15.31 \mathrm{ppm}$ after $24 \mathrm{~h}$ and $11.01 \mathrm{ppm}$ after $48 \mathrm{~h}$ [16]. Based on the above description, the researchers wanted to see the effectiveness of $A$. vera leaf extract to death of Aedes sp.

\section{MATERIALS AND METHODS}

The method of research was used true experiment design with posttest only control group design. This study research has approved to Committee Ethical Clearance in University of North Sumatera. Tools and materials used in the study include:

\section{Materials}

1. A. vera leaves $1000 \mathrm{~g}$ fresh

2. $96 \%$ ethanol as a solution in extracting $A$. vera leaves

3. Aedes $s p$ instar larvae III/IV water

4. Phytochemical screening material.

\section{Tool}

a. Tools for making A vera leaf extract: Scales, dryer, parchment paper, percolation tool, aluminum foil, cotton, and bottle

b. Tools for testing effectiveness: $350 \mathrm{ml}$ plastic cup containing $200 \mathrm{ml}$ water, pipette larvae, kassa nylon, beaker glass, clock, magnifying glass, and observation sheet.

\section{Population and sample}

Eggs obtained from the Health Research and Development Agency of Pangandaran Disease Control, West Java, and it hatched in Parasitology Laboratory Faculty of Medicine, University of North Sumatra. The sample research was 700 Aedes sp larvae wherein each test group was 25 Aedes sp larvae in each research glass [29].

\section{Inclusion criteria}

The following criteria were included in this study:

1. Aedes sp larvae in living conditions and have reached instar III/IV

2. Aedes sp larvae which move actively.

The glass of study with into seven groups which 1 cup contains water as a negative control, 5 cups contains $A$. vera leaf extract at concentration 20 ppm; 40 ppm; 60 ppm; 80 ppm; and 100 ppm, and 1 cup again as a positive control contains abate $\AA 1$ ppm [29].

\section{Methods}

Making A. vera leaf extract

The method of taking aloe leaves was done purposively without comparing with the same plant from other regions. A. vera leaves from Pasar V Timur, Medan Estate Complex, Percut Sei Tuan, and Deli Serdang. A. vera leaves were collected, cleaned from the dirt, washed with water until clean, then envy transverse with a thickness of approximately $0.5 \mathrm{~mm}$ and dried in a drying cupboard with a temperature of $50^{\circ} \mathrm{C}$. Then if it was smoothed with a blender and stored in a sealed container and protected from sunlight. A. vera has been processed with soaked in $96 \%$ ethanol for $3 \mathrm{~h}$ then insert it into the percolator tool carefully until submerged later, close the percolation tool, and leave for $24 \mathrm{~h}$. Open tap percolation then let it flow at a speed of $1 \mathrm{ml} / \mathrm{min}$ then add back ethanol $96 \%$ repeatedly so that $A$. vera remains submerged. Percolation was stopping when the droplets were no longer colored, the result of the percolation is called liquid extract and then evaporated to obtain a thickened extract. Then, extract the next in the freeze dryer for $24 \mathrm{~h}$. Keep the container closed [9].

\section{Observation of larvicidal effects}

Observation of larvicidal effect was done by:

a. Enter 25 larvae into each glass of research that has been mixed A. vera leaf extract with various concentrations: $20 \mathrm{ppm} ; 40 \mathrm{ppm}$; $60 \mathrm{ppm}$; $80 \mathrm{ppm}$; and $100 \mathrm{ppm}$, negative control (water) and abate ${ }^{\circledR}(1 \mathrm{ppm})$ as a positive control

b. Observe the number of dead larvae in the studied glass at 180, 360, 1440, and 2880 min (Fig. 1)

c. Record the results on the observation sheet.

\section{Phytochemical screening}

Phytochemical screening of $A$. vera leaf extract includes an examination of alkaloid group compounds, glycosides, saponins, tannins, and flavonoids.

\section{Data analysis}

The observed data by one-way analysis of variance (ANOVA) test to a difference of a number of Aedes $s p$ larvae deaths among the test group, then least significance different (LSD) test to find the significant difference and probit analysis to assess the toxicity of larvicidal effect A. vera leaf extract to Aedes sp larvae.

\section{RESULTS}

\section{Phytochemical screening}

phytochemical analysis was an analysis on the variety of organic compounds in the form and in stack by living things.[14]. Phytochemical screening was performed to determine the content34 of secondary metabolites or active compounds on aloe leaf extracts 35 qualitatively. The results of $A$. vera phytochemical screening are shown 36in Table 1 :

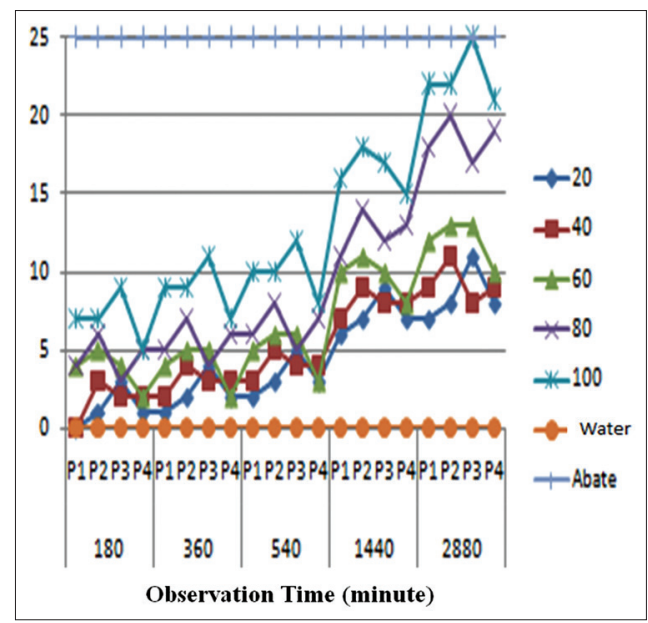

Fig. 1: Graph of mortality rate

Table 1: Phytochemical screening

\begin{tabular}{lc}
\hline Active compounds result & \\
\hline Steroid/terpenoid & - \\
Alkaloid & + \\
Glycosides & + \\
Saponin & + \\
Tannin & + \\
Flavonoid & + \\
Minyak atsiri & + \\
\hline
\end{tabular}




\section{Data analysis}

It is average percentage of larval mortality rates shown in the following Table 2:

To find out whether there was an average difference between several concentrations and the time to death of the larvae with one-way ANOVA test. Before performing the one-way ANOVA test, the data have must normally distribution (Table 3 ).

Amount of data used $<50$, the test used was Shapiro-Wilk normality test [8]. Based on Table 4, it can be seen that the overall concentration at all hours of observation, the significance value was above $5 \%$ ( $p>0.05)$, the normal distribution. Because the data were normally distribution, ANOVA one-way test shown in the following Table 4:

Based on Table 4, it can be seen that the significance value obtained was $0.000(<0.05)$, so it can be said that there was a significant difference in the average death of larvae. To determine groups have different larval mortality, it shows a post hoc test with LSD before doing a post hoc test, previously to determine whether the data is homogeneous or not with variance analysis. The following was the result of the analysis of data variance test given following in Table 5 :

Table 5 shows that the observation time from $180 \mathrm{~min}$ to $2880 \mathrm{~min}$ ( $>0.05$ ) was significant because of $p>0.05$, the mortality of homogeneous larvae. It continued with the LSD test after the LSD test then proceeds with probit analysis.

A probit analysis was used to determine concentrations in killing larvae. A. vera leaf extract concentration was effective to kill $50 \%$ of test larvae with $\mathrm{LC}_{50}$. It was the result of probit analysis.

From Table 6, the $\mathrm{LC}_{50}$ value of $80.5 \mathrm{ppm}$ at $1440 \mathrm{~min}$.

\section{DISCUSSION}

This research used $A$. vera leaf extract that for know effectiveness of $A$. vera leaf extract to mortality Aedes $s p$ larvae Instar III and IV. A. vera leaves can act as insecticides and larvacides without damaging other organisms and the environment due to the content of secondary metabolite compounds which are toxic substances to mosquito larvae [11]. To find out the secondary metabolite content of $A$. vera leaf extract must do phytochemical screening [17] was performed the qualitative test showed A. vera contains alkaloid compound, glycoside, saponin, tannin, and flavonoid (Table 1). Pedro et al. and Ramesh et al. also performed secondary metabolite screening on A. vera extracts and secondary metabolites which may be alkaloids, saponins, tannins, flavonoids, and glycosides. These compounds synergize and cause death in Aedes sp larvae [20,21].

Alkaloids were as a stomach poison. It is also able to inhibit the growth of insects, especially three hormones in insects, namely, the brain hormone, edition hormone, and growth hormone (juvenile hormone). The development of these hormones can cause metamorphosis failure [28].

Glycoside was a secondary metabolite in plants that are stomach poison, where the way glycosides work by restraining appetite from the mosquito larvae [27]. Saponins are stomach poison for coldblooded animals, including mosquitoes. Saponins can decrease the surface permeability membrane of larval digestive tract, so the wall of the larval digestive becomes corrosive. Saponins can inhibit the action of enzymes that result in decreased digestive activity and the use of protein for insects [28].

Tannin acts as a plant defense by blocking insects from digesting food. Consequently, it will be a decrease in growth and disrupt water absorption so it can cause death to the larvae [22].

Flavonoids were plant-defensive compounds that can inhibit the digestive tract of insects and are also toxic. Flavonoids work as a respiratory inhibitor or as a respiratory toxin. Flavonoids have a way of working by entering into the body of the larvae through the respiratory system which then causes wilting on the nerves and damage to the spiral consequently insects cannot breathe and eventually die [6].

In this research, a total of 700 Aedes sp Instar III/IV into 7 test groups of 20 ppm; 40 ppm; 60 ppm; 80 ppm; and 100 ppm; negative control (water) and positive control (abate ${ }^{\circledR} 1 \mathrm{ppm}$ ). Each group contains 25 larvae into $200 \mathrm{ml}$ water. Based on the results of the study, Table 2 shows that larval mortality has started to occur with the concentration of Aloe leaf extract $60 \mathrm{ppm}$ at minute $180 \mathrm{~min}$. Then, it can be seen that the average percentage of larval mortality in water and abate was 0 and 25. It means that water only a soaking medium so it does not have larvicidal power.

Abate ${ }^{\circledR}$ reaches to death $100 \%$ at $180 \mathrm{~min}$, and it can be shown that abate has good larvicidal power. While aloe leaf extract of $100 \mathrm{ppm}$ concentration takes 2880 min to reach $100 \%$, because if its high concentration of $A$. vera extract can accelerate the time required to kill Aedes sp larvae. While abate ${ }^{\circledR}$ takes a short time because abate ${ }^{\circledR}$ was an organic phosphate group pesticide that inhibits cholinesterase enzyme causing disruption to nerve activity due to the accumulation of acetylcholine at nerve endings when this cholinesterase enzyme was inhibited then hydrolysis of acetylcholine does not occur which will cause spasticity and death on the larvae [18]. The dosage used in abate ${ }^{\circledR}$ was $10 \mathrm{~g}$ for every $100 \mathrm{~L}$ of water equivalent to $1 \mathrm{ppm}$ [10].

Based on the result of the data distribution test, it was normal distribution and from ANOVA one-way test (Table 4) shows that there was a significant difference the average larvae mortality $(p>0.05)$. To determine the difference average death of larvae, post hoc test was done using LSD. Before performing a post hoc test, it performs a test variant to determine whether the data were homogeneous or not then continued LSD test. Probit analysis was a method to find out effective concentration in killing larvae (Tabel 6), the result of probit analysis, a value LC50 80,5 at $1440 \mathrm{~min}$. This concentration was most effective the killing Aedes sp larvae. According to the WHO, a good natural larvacide was a larvicidal effectivity at concentrations below $100 \mathrm{ppm}$, whereas in minutes 180540 the $\mathrm{LC}_{50}$ value is above $100 \mathrm{ppm}$. The $\mathrm{LC}_{50}$ value at $2880 \mathrm{~min}$ was less effective than 1440 as it takes longer observation time.

Research conducted by Subramaniam et al., obtained the value of $\mathrm{LC}_{50}$ in Aedes sp instar Larvae I, II, III, and IV is 162,$74 ; 201,43 ; 253,30$; and

Table 2: Average percentage of larvae mortality at various observation time

\begin{tabular}{|c|c|c|c|c|c|}
\hline \multirow[t]{2}{*}{ Concentration } & \multicolumn{5}{|c|}{ Time observation (min) } \\
\hline & $180(\%)$ & $360(\%)$ & $540(\%)$ & $1440(\%)$ & $2880(\%)$ \\
\hline $20 \mathrm{ppm}$ & 5 & 9 & 13 & 29 & 34 \\
\hline $40 \mathrm{ppm}$ & 7 & 12 & 16 & 32 & 37 \\
\hline $60 \mathrm{ppm}$ & 15 & 16 & 20 & 39 & 48 \\
\hline $80 \mathrm{ppm}$ & 18 & 22 & 26 & 50 & 74 \\
\hline $100 \mathrm{ppm}$ & 28 & 36 & 40 & 66 & 90 \\
\hline Water & 0 & 0 & 0 & 0 & 0 \\
\hline Abate & 100 & 100 & 100 & 100 & 100 \\
\hline
\end{tabular}


Table 3: Test result of data normality

\begin{tabular}{|c|c|c|c|}
\hline \multirow{2}{*}{$\begin{array}{l}\text { Observation } \\
\text { (min) }\end{array}$} & \multicolumn{3}{|l|}{ Shapiro-Wilk } \\
\hline & $\begin{array}{l}\text { Concentration } \\
(\mathrm{ppm})\end{array}$ & $\begin{array}{l}\text { Significant } \\
\text { (p) }\end{array}$ & Information \\
\hline \multirow[t]{5}{*}{180} & 20 & 0.406 & Normal \\
\hline & 40 & 0.406 & Normal \\
\hline & 60 & 0.406 & Normal \\
\hline & 80 & 0.972 & Normal \\
\hline & 100 & 0.683 & Normal \\
\hline \multirow[t]{5}{*}{360} & 20 & 0.406 & Normal \\
\hline & 40 & 0.683 & Normal \\
\hline & 60 & 0.161 & Normal \\
\hline & 80 & 0.972 & Normal \\
\hline & 100 & 0.683 & Normal \\
\hline \multirow[t]{7}{*}{540} & 20 & 0.406 & Normal \\
\hline & 40 & 0.683 & Normal \\
\hline & 60 & 0.161 & Normal \\
\hline & 80 & 0.972 & Normal \\
\hline & 100 & 0.683 & Normal \\
\hline & 20 & 0.406 & Normal \\
\hline & 40 & 0.683 & Normal \\
\hline \multirow[t]{5}{*}{1440 menit } & 60 & 0.406 & Normal \\
\hline & 80 & 0.224 & Normal \\
\hline & 100 & 0.683 & Normal \\
\hline & 20 & 0.195 & Normal \\
\hline & 40 & 0.406 & Normal \\
\hline \multirow[t]{3}{*}{2880 menit } & 60 & 0.161 & Normal \\
\hline & 80 & 0.972 & Normal \\
\hline & 100 & 0.195 & Normal \\
\hline
\end{tabular}

Table 4: Result of one-way ANOVA

\begin{tabular}{lll}
\hline Observation (min) & Significant (p) & Information \\
\hline 180 & 0.000 & Significant \\
360 & 0.000 & Significant \\
540 & 0.000 & Significant \\
1440 & 0.000 & Significant \\
2880 & 0.000 & Significant \\
\hline
\end{tabular}

ANOVA: Analysis of variance

Table 5: Data varian test

\begin{tabular}{lll}
\hline Observation (min) & Significant $(\mathbf{p})$ & Information \\
\hline 180 & 0.164 & Homogenous \\
360 & 0.137 & Homogenous \\
540 & 0.137 & Homogenous \\
1440 & 0.074 & Homogenous \\
2880 & 0.061 & Homogenous \\
\hline
\end{tabular}

Table 6: $\mathrm{LC}_{50}$ value

\begin{tabular}{ll}
\hline Time (min) & LC $_{\mathbf{5 0}}(\mathbf{p p m})$ \\
\hline 180 & 155 \\
360 & 124.6 \\
540 & 117.1 \\
1440 & 80.5 \\
2880 & 54.2 \\
\hline
\end{tabular}

$\mathrm{LC}_{50}$ : Lethal concentration median

300.05 ppm. LC $_{50}$ value was above 100 ppm; because Subramaniam et al. solvent used was petroleum ether. It was a non-polar solution. Where it solvents will attract non-polar compounds and polar solvents will attract polar compounds. In this study, it used was ethanol, because ethanol was a solvent with high polarity [23]. In A. vera leaf extracts, secondary metabolites that act as natural larvacides are polar compounds (flavonoids, saponins, glycosides, and tannins).
The high mortality rate because of active compounds to larvae such as alkaloids, glycosides, saponins, tannins, flavonoids that are in direct contact with the test larvae. It accumulates a lot and enters the body which effects in the life activity disturbed and ultimately leads to death.

\section{CONCLUSION}

A. vera extract can be larvicidal because it has the secondary metabolite compounds which toxic substances to mosquito larvae. The secondary metabolite A. vera extract consists of alkaloids, saponins, tannins, flavonoids and glycosides. The high mortality rate because of accumulates secondary metabolite which effects in the life activity disturbe then lead to death [30]. A. vera leaf extract concentration was effective to kill $50 \%$ of test larvae with LC50 value of 80,5 ppm at 1440 min. it can be said to be more potent because by WHO (2005) is natural larvicide which effectivity value at the concentration above 100 ppm [31].

\section{CONFLICTS OF INTEREST}

All authors have none to declare.

\section{REFERENCES}

1. Akinyele BO, Odiyi AC. Comparative study of the vegetative morphology and the existing taxonomic status of Aloe vera L. J Plant Sci 2007;2:558-63

2. Gosh A, Nandita C, Gautam C. Plant extracts as potential mosquitos larvicides. Indian J Med Res 2012;135:581-98.

3. Bahri S, Syafriati T. Mewaspadai munculnya beberapa penyakit hewan menularstrategis di indonesia terkait dengan pemanasan global danperubahanIklim. Wartozoa 2011;21:25-39.

4. Boesri H. Biologidan peranan Aedes albopictus (Skuse) 1894 sebagai penular penyakit. Aspirator 2011;3:117-25.

5. Cania EB, Setyaningrum E. Uji efektifitas larvasida ekstrak daun legundi (Vitextrivolia)terhadap larva Aedes aegypti. J Kedokteran Unila 2013;2:52-60.

6. Anwar C, Lavita RA, Handayani D. Identifikasidan distribusi nyamuk Aedes Sp sebagai vektor penyakit demam berdarah dengue di beberapa daerah di sumatera selatan. Majalah Kedokteran Sriwijaya 2014;46:111-7

7. Chore JK, Obonyo M, Wachira FN, Mireji PO. Larvicidal activity of selected Aloe species Against Aedes aegypti. J Insect Sci 2014;14:pii: 202.

8. Dahlan, M. Sopiyudin. Besar Sampeldan Cara Pengambilan Sampeldalam Penelitian Kedokterandan Kesehatan. Jakarta: Salemba Medika; 2009

9. Departement Kesehatan Republik Indonesia (Depkes RI). Parameter Standar Umum Ekstrak Tumbuhan Obat. CetakanPertama. Jakarta: Departement Kesehatan Republik Indonesia; 2000.

10. Departemen Kesehatan Republik Indonesia (Depkes RI). Buletin Jendela Epidemiologi Demam Berdarah Dengue. Pusat Data danSurveilans Epidemiologi. Jakarta: Kementrian Kesehatan Republik Indonesia; 2014

11. Gomathi RI, Karpagam S. Larvicidal activity of Monsteraadansonii plant extracts against Culex quinequfaciatus. J Pharm Phytochem 2014;3:160-2.

12. Guzman A, Isturiz RE. Update on the global spread of dengue. Int J Antimicrob Agents 2010;36 Suppl 1:540-2.

13. Herms W. Medical Entomology. United States: The Macmillan Company; 2006.

14. Kasminah. Aktifitas Anti oksidan Rumput Laut Halymeniadurvillaeidengan Pelarut Non Polar, Semi Polar danPolar. Surabaya: Universitas Airlangga; 2016.

15. Kovendan K, Murugan K. Effective of medicinal plants on the mosquito vectors from the different agrolimatic regions of Tamil nadu, India. Adv Environ Biol 2011;5:335-4.

16. Maurya P, Mohan L, Sharma P, Srivastava CN. Larval susceptibility of Aloe barbadensis and Cannabis sativaagainst Culex quinquefasciatus, the filariasis vector. J Environ Biol 2008;29:941-3.

17. Mungenge C, Zimudzi C, Zimba M, Nhiwatiwa T. Phytochemical screening, cytotoxicity and insecticidal activity of the fish poison plant Synaptolepisalternifolia Oliv. (Thymelaeaceae). J Pharm Phytochem 2014;2:15-9.

18. Ndione RD, Omar F, Ndiaye M. Toxic effects of neem products (Azadirachta indica A. Juss) on Aedes aegypti Linnaeus 1762 larvae. 
Afr J Biotechnol 2007:6:2846-54.

19. Panghiyangan R, Marlinae L, Isnaini, Rahman F. Potential of turmeric rhizome essential oils against Aedes aegypti Larvae. Univ Med 2012;31:20-6.

20. Pedro MG, Aubrey NA, Bryle Adrian LE, Santos MF. Larvicidal activity of selected plant extracts againts the dengue vector Aedes aegypti Mosquito. Int Res J Biol Sci 2014;3:23-32.

21. Ramesh K, Ashok KS, Rajarajan S. Larvicidal activity of Aloe vera leaf extract on Culex Salinarius. Curr Res Microbiol Biotechnol 2013;1:124-6.

22. Setyaningsih PN. Efektifitas Ekstrak Etanol Daun Salam (Syzygium polyanthum) sebagai Larvasidaterhadap Larva Nyamuk Aedes aegypti. Unud; 2015.

23. Sermakkani M, Thangapandian V. Gc-Ms analysis of Cassia italic Leaf methanol extract. Asian J Pharm Clin Res 2012;4:90-4.

24. Shivakumar M, Srinivasan SR, Natarajan D. Larvicidal potential of some Indian medicinal plant extracts against Aedes aegypti. Asian J Pharm Clin Res 2013;6:77-80.

25. Susanti AD, Ardiana D, Gumelar PG, Bening YG. Polaritas Pelarut Sebagai Pertimbangandalam Pemilihan Pelarutuntuk Ekstraksi Minyak
Bekatuldari Bekatul Varietas Ketan (Oriza sativa glatinosa). Simposium Nasional RAPI XI FT UMS-2012.

26. Subramaniam J, Kovendan K, Kumar MP, Murugan K, Walton W. Mosquito larvicidal activity of Aloe vera (Family: Liliaceae) leaf extract and Bacillus sphaericus, against. Saudi J Biol Sci 2012;19:503-9.

27. Arivoli TS, John R. Larvicidal efficacy of plant extract againts the malaria vector Anopheles stephensi Liston. J Med Sci 2012;7:77-80.

28. Lumowa SV, Nova TP. Larvicidal activity of Syzygium polyanthum W. leaf extract against Aedes aegypti $L$ larvae. Prog Health Sci 2014;5:102.

29. Wahyuni D. Toksisitas Ekstrak Tanamansebagai Bahan Dasar Biopeptisida Baru Pembasmi Larva Nyamuk Aedes aegypti (Ekstrak Daun Sirih, Ekstrak Biji Pepaya, dan Ekstrak Biji Srikaya) Berdasarkan Hasil Penelitian. Unej; 2014.

30. Wardani RS, Mifbakhuddin, Yokorinanti K. Pengaruh konsentrasi ekstrak daun tembelekkan (Lantana camara)Terhadap Kematian larva Aedes aegypti. J Unimus 2010;6(2):30-8.

31. World Health Organization (WHO). Guidelines for Laboratory and Field Testing of Mosquito Larvicides. Geneva: WHO; 2005.

32. World Health Organization WHO. Position Statment on Integrated Vector management. Geneva: WHO; 2008. 